\title{
The Impact of Network Literature Website Service Quality on Reader Loyalty Based on Technology Acceptance Model
}

\author{
Yangjing $\mathrm{Xu}^{1, *}$ \\ ${ }^{1}$ School of Business Administration, Southwestern University of Finance and Economics, Chengdu, Sichuan 611130, \\ China \\ *Corresponding author. Email: xuyangjingHannah@163.com
}

\begin{abstract}
Based on the Technology Acceptance Model (TAM), this paper introduces the service quality theory into the field of network literature websites, and studies the mechanism of the service quality of network literature websites on reader loyalty. It is found through research that the service quality of online literature websites has a significant positive impact on reader loyalty; the service quality of network literature websites has a significant positive impact on perceived convenience; the perceived convenience has a significant positive impact on reader loyalty; and perceived convenience plays a part of the mediating effect in the service quality of network literature websites on reader loyalty. This research not only provides a certain support for the improvement of the related theories about the service quality of online literature websites in China, but also further explores the feasible path for the development of current online literature websites in China.
\end{abstract}

Keywords: network literature website, service quality, Technology Acceptance Model, perceived convenience, reader loyalty

\section{INTRODUCTION}

Network literature is a new type of literature that uses the Internet as a carrier of communication and can interact with readers. The continuous increase of the number of Internet users in China has greatly increased the popularity of digital reading, and the development of network literature has been extremely vigorous. As of the end of 2018, the total size of China's network literature market reached 16.2 billion yuan, and at the end of 2019 it was approaching the 20 billion yuan [1]. As a direct channel for readers to access network literature at this stage, the quality of the service provided by online literature websites will have a profound impact on readers' reading experience, and then affect readers' behavior and attitude characteristics, especially reader loyalty. Therefore, it is of great significance to explore how to improve the service quality of online literature websites to promote the formation of reader loyalty.

In the existing literature research, many scholars have established the TAM model to study the impact of website design on customer loyalty, but there is still little research on reader loyalty. In the research results of Davis et al., The TAM model was discussed for the first time. It believed that there is a clear causal chain between perceived ease of use, perceived availability, use attitude, use willingness, and use behavior [2]. In addition, Wang Kai [3] pointed out that perceived usefulness and ease of use affect customer loyalty.

In addition, Diego Bufquin et al. found that improving the service quality of hotel websites can effectively increase the customer's willingness to book [4]. Therefore, this article also carried out targeted research and discussion on the quality of service on the network literature website. Pasuraman, Zeitharml, and Berry [5] first proposed a classification method for website service quality. In the research results, the content of service quality was combed and summarized. And they also creatively proposed the SERVQUAL model. In the study of e-commerce platforms, Jiang Pinyu [6] combined the characteristics of e-commerce platforms to evolve this model. Therefore, this article will combine the characteristics of network literature websites to divide the quality of website services and analyze the mechanism that affects readers.

At present, there are many researches on the service quality based on online stores and social media. However, from the perspective of improving service quality to build a better network literature website, the literature analyzing the factors that affect the loyalty of website readers is almost zero. Therefore, based on the 
TAM model, this article takes the service quality model as the starting point, explores the mechanism between the overall design of network literature websites and reader loyalty, and puts up with some suggestions on practical issues like how online literature websites improve reader loyalty and website popularity.

\section{THEORETICAL BASIS AND RESEARCH HYPOTHESIS}

Davis et al. [2] pointed out that the individual's acceptance of a certain thing is determined by the individual's willingness to use. Perceived ease of use and usefulness and other external factors affect consumers' consumption choices. Therefore, based on the TAM model, this article integrates the two factors into perceived convenience, and uses this as an intermediary variable to analyze how reader loyalty is affected by the service quality of network literature websites.

\section{A. Service quality}

Glorus [7] first introduced the concept of quality to the service domain, and proposed a customer-perceived service quality model based on cognitive psychology. He divided service quality into technical quality and functional quality, and proposed service as process and service as result. In order to study the development path of high-quality services in different industries, Pasuraman et al. [5] investigated and analyzed consumer consumption behavior from multiple perspectives. And they also proposed the SERVQUAL model to analyze the service perception mechanism of customers in different industries, and used tangibility, reliability, responsiveness, assurance, and empathy to express the impact. Different scholars have deleted and modified measurement items according to different situations. For example, Headley and Miller reduced the five measurement items to reliability, credibility, and empathy for the medical industry; Jiang [8] and others kept four of the measurement items in the research of information systems, excluding the tangible items [9].

Some scholars have actively introduced this concept into the field of researching network service quality. Zeithaml proposed the concept model of electronic service quality based on the traditional SERVQUAL concept architecture, namely the e-SERVQUAL model [10]. The model contains 11 dimensions, including the beauty of the webpage, the convenience of navigation, customization, security, and efficiency. According to Lociacono's research results, the evaluation dimensions include convenience, transaction, information quality, and entertainment [11]. Cristobal also provided an evaluation system including page optimization, website design, and order management through a questionnaire survey [12].
In researching the e-commerce platform, Jiang Pinyu [6] embodied "tangibility" into "aesthetics", modified "empathy" into "caring", and combined the two dimensions of "reliability" and "assurance" into "reliability". Because the e-commerce platform and network literature website are all aimed at expanding customers by optimizing the service quality, this article will use the views of Jiang Pinyu [6] and others to try to explore the impact of network design on customer loyalty from the aspects of aesthetics, caring and information content.

\section{B. Perceived convenience}

The TAM model given by Venkatesh uses consumers' perceptions of the usefulness and ease of information technology as mediating variables, and analyzes the specific factors affecting user behavior [2]. The so-called perceived usefulness mainly refers to the perception of whether a research object is useful for the product used; and the perceived ease of use mainly refers to the perception of whether a research object is easy to use the product. Through research, Yang $\mathrm{H}$ found that whether in the popularization and application of the Internet, or in the research on other emerging technologies, or in how the media is accepted and recognized by consumers, the impact of the above two variables has been verified. [13]. Fenech has used perceived usefulness and ease of use to study online shopping behavior [14]. Van der Heijden introduced perceived fun to explain consumers' use of the website [15]. In order to simplify the research, the above two variables are integrated and expressed by perceived convenience.

\section{Reader loyalty}

Brown and Cunningham first proposed the concept of loyalty. But until now, the academic circle still does not have a unified definition of customer loyalty [16]. Generally speaking, there are three representative views: behavioral loyalty, attitude loyalty, and comprehensive loyalty. Magatef and Tomalieh explored customer behavior characteristics and believed that customer loyalty is related to behavioral loyalty, including purchase frequency, purchase volume, conversion rate, and customer retention rate [17]. In Ajzen's research results, emphasis is placed on attitude loyalty, that is, the positive attitude of customers towards consumer objects. [18] On this basis, Zeitharml affirmed the attitude loyalty theory and emphasized that customer loyalty represents the customer's willingness to build a long-term stable relationship with a certain product or a certain manufacturer [19]. In terms of comprehensive loyalty theory, Dick et al.'s research results point out that the high-frequency consumption behavior based on positive attitudes is the core content of customer loyalty, and based on this, they further decomposed customer loyalty into two aspects of 
attitude and behavior, and further subdivided according to the degree of loyalty.

The author adopted the viewpoints generally recognized by scholars in the world, and divided customer loyalty into two aspects of behavioral loyalty and attitude loyalty according to Dick's and Basu's classification. It is believed that not only the behavioral characteristics of readers (such as repeated purchases, cross-buying behaviors), but also customer attitude characteristics (such as preferences for websites and services) need to be considered.

\section{Research hypothesis}

1) Network service quality and perceived convenience: Liu and Amett analyzed e-commerce platforms to reach the conclusion that the quality of information and services, the use of the system (easy to use and confidentiality), and the fun play a vital role in a successful website [21]. Gong Xiaoqing [22] and others believe that web design plays a key role in consumers' evaluation of online stores, and excessively bright colors should be avoided to cause discomfort to consumers. And when web page typesetting is carried out, the rationality of typesetting must be ensured to avoid cluttered typesetting affecting consumer perception. Tang Yijun [23] pointed out that the personalized design including the retrieval function is very convenient and easy for consumers to use, and it should be emphasized in the process of website design. Wei Chao [24] and others believe that web page content and timeliness have an impact on web page quality. The following assumptions are made:

H1: Network service quality positively impacts perceived availability.

H1a: Aesthetics positively affects perceived usability.

H1b: Caring positively affects perceived availability.

H1c: Information content positively affects perceived availability.

2) Network service quality and reader loyalty: $\mathrm{Ha}$ and others pointed out in the research results that the use experience has important practical significance for website users, and it is also an important index parameter that affects whether they use the website. If the website can provide customers with the desired experience, then these customers are more likely to become loyal customers of the website [25]. Shi Da proposed that the educational, entertaining, aesthetic, and forsaking the world nature of the website are positively related to customer loyalty [26]. Gomman's research results have also proposed five factors that help strengthen customer repeat visits and purchases [27]. Therefore, this article makes the following assumptions:

H2: Network service quality positively affects customer loyalty

$\mathrm{H} 2 \mathrm{a}$ : aesthetics positively affects customer loyalty

$\mathrm{H} 2 \mathrm{~b}$ : Caring positively affects customer loyalty

H2c: Information content positively affects customer loyalty

3) Perceived convenience and reader loyalty: According to the above, perceived ease of use and usefulness together constitute perceived convenience. A large number of studies have shown that the above two factors have a strong ability to explain changes in consumer loyalty. Martins have shown that perceived usefulness has a significant positive impact on user intentions [28]. Hsi-Peng Lu et al. used a technology acceptance model and replaced ease of use with "easy access", and found that the above two factors have a positive impact on the customer's final choice behavior [29]. Zhang Fangfang [30] also analyzed this issue and found that the above two factors will promote consumers to choose a certain product, so they have a positive impact on consumption decisions and can effectively strengthen readers' loyalty.

Therefore, the following assumptions are made: loyalty

H3: Perceived convenience positively affects reader

4) Mediation of perceived convenience: According to the previous discussion, it is clear that the quality of network services affects perceived convenience, and perceived convenience determines reader loyalty. FENECH T [31] and others mentioned that perceived usefulness and perceived ease of use affect their users' willingness to purchase, and that perceived usefulness directly has a positive effect on purchase willingness. Although there are few literatures that directly discuss the mediating role of perceived convenience, some scholars have used variables similar to the definition of perceived convenience as mediating variables. McDougal et al. found that customer perceived value can promote the formation of service industry loyalty [32] through empirical research on the service industry. Zhou Jie and He Luping [32] defined customer delight as a service that truly identifies and captures customer needs when studying customer loyalty, and regards it as an intermediary variable for targeted research and discussion. Accordingly, this study assumes:

H4: Perceived convenience plays an intermediary role in the relationship between network service quality and customer loyalty. 
H4a: Perceived convenience plays an intermediary role in the relationship between the aesthetics of network service quality and customer loyalty.

H4b: Perceived convenience plays an intermediary role in the relationship between caring of network service quality and customer loyalty.
H4c: Perceived convenience plays an intermediary role in the relationship between information content of network service quality and customer loyalty.

Based on the hypothesis proposed above and sorting out related theoretical research results, the author proposed a conceptual model of "website design for customer loyalty" (see "Fig. 1").

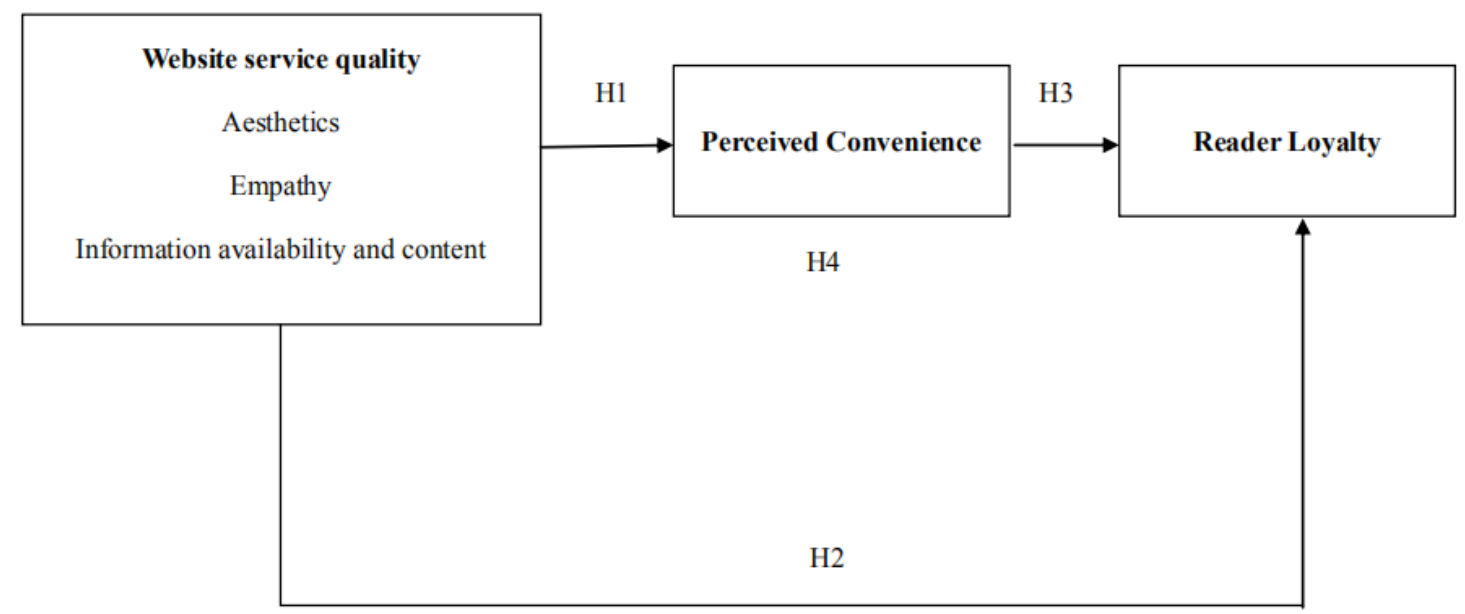

Fig. 1. The theoretical model of this study.

\section{RESEARCH DESIGN}

\section{A. Variable design}

In this study, mature scales were used to measure the five variables of aesthetics, caring, information content, perceived convenience, and reader loyalty. This study also made semantic changes according to the specific context of the website design. Respondents can fill in or choose according to their actual situation.

1) Independent variable - quality of website service: After modifying the scales of Jiang Pinyu [6], Shih [34], and Van Riel [35], this article divides the website service quality from three dimensions: aesthetics, caring, and information content.

2) Intermediate variable - perceived convenience: This paper integrates the perceived usefulness and perceived ease of use scales proposed by Davis [2], and their reliability and validity have been tested by empirical research by Palvou [36] and others.

3) Dependent variable - reader loyalty: The items in this section are appropriately modified based on Dick and Basu's research on customer loyalty, including behavioral loyalty and attitude loyalty [20].

Because demographic data affect reader loyalty to a certain extent, this study uses gender, age, and education as control variables.

The Likert scale was used in this study. "1" means "strongly disagree" and "5" means "strongly agree".
Data analysis was performed using the latest version of SPSS25.0 software.

\section{B. Data collection and sample data descriptive statistics of demographic characteristics}

This study selects readers who have read online literature through the website as the experimental research object. Through a variety of channels such as the Internet platform, a questionnaire survey was conducted, and Baidu Post Bar and the Starting point Chinese net, Xiaoxiang Academy, Jinjiang Literature City and other readers gathered sites served as distribution channels. The total number of questionnaires was 328 , and 320 were effectively recovered with a recovery rate of $97.56 \%$. After excluding invalid questionnaires with obvious "Z"-type, that is, the test items are mostly extreme values 1 or 5 , and the median value is mostly 3 , the valid sample rate is $95.94 \%$, that is, the final valid sample is 307 , which meets the requirement that the effective sample size is 5 times the measurement item. This paper makes descriptive statistics on the demographic characteristics of the sample data to facilitate a clearer understanding of the structural characteristics of the sample. (See "Table I"). 
TABLE I. DEMOGRAPHIC CHARACTERISTICS OF THE SURVEY SAMPLE

\begin{tabular}{|c|l|l|l|}
\hline Name & \multicolumn{1}{|c|}{ Category } & \multicolumn{1}{c|}{ Pumber of samples } & \multicolumn{1}{c|}{ Percentage } \\
\hline \multirow{3}{*}{ Gender } & Male & 175 & $57.00 \%$ \\
\cline { 2 - 4 } & Female & 132 & $43.00 \%$ \\
\hline \multirow{3}{*}{ Education level } & Under 20 years old & 16 & $5.21 \%$ \\
\cline { 2 - 4 } & 20 to 30 years old & 213 & $69.38 \%$ \\
\cline { 2 - 4 } & Above 30 years old & 77 & $25.08 \%$ \\
\hline \multirow{3}{*}{} & High school and below & 67 & $21.82 \%$ \\
\cline { 2 - 4 } & Junior college & 68 & $22.15 \%$ \\
\cline { 2 - 4 } & Undergraduate & 111 & $36.16 \%$ \\
\cline { 2 - 3 } & Master degree and above & 60 & $19.54 \%$ \\
\hline
\end{tabular}

\section{DATA ANALYSIS AND HYPOTHESIS TESTING}

\section{A. Reliability, validity test and factor analysis}

To ensure the validity of the data, reliability tests, reliability tests, and factor analysis were carried out.

Reliability refers to the accuracy and correctness of the data studied. After passing the Cronbach's Alpha test for reliability, the results all exceeded the standard value of 0.7 , proving that the scale has high reliability, that is, it passed the reliability test.
Validity refers to how accurately the data in the questionnaire measure things. Using $\mathrm{KMO}$ and Bartlett test validity, the results all exceeded the standard value of 0.7 , which proved to have good credibility; the Bartlett test result was significant $(\mathrm{p}<0.001)$ and met the preset conditions. Finally, the factor analysis method was used to calculate the factor load, and the results all exceeded the standard value of 0.5 , indicating that the convergence validity is ideal. The specific analysis results are shown in the following "Table II".

TABLE II. RELIABILITY AND VALIDITY ANALYSIS RESULTS

\begin{tabular}{|c|c|c|c|c|c|}
\hline Variable name & & Measure item & Factor load & Cronbach'a & KMO \\
\hline \multirow{18}{*}{ Website service quality } & \multirow{6}{*}{ Aesthetics (IB) } & IB1 & .656 & \multirow{6}{*}{.827} & \multirow{6}{*}{.863} \\
\hline & & IB2 & .635 & & \\
\hline & & IB3 & .779 & & \\
\hline & & IB4 & .798 & & \\
\hline & & IB5 & .780 & & \\
\hline & & IB6 & .740 & & \\
\hline & \multirow{6}{*}{ Caring (IC) } & IC1 & .693 & \multirow{6}{*}{.850} & \multirow{6}{*}{.879} \\
\hline & & IC2 & .701 & & \\
\hline & & IC3 & .808 & & \\
\hline & & IC4 & .797 & & \\
\hline & & IC5 & .774 & & \\
\hline & & IC6 & .762 & & \\
\hline & \multirow{6}{*}{ Information Content (II) } & II1 & .767 & \multirow{6}{*}{.839} & \multirow{6}{*}{.876} \\
\hline & & II 2 & .609 & & \\
\hline & & III & .754 & & \\
\hline & & II4 & .782 & & \\
\hline & & II5 & .759 & & \\
\hline & & II6 & .790 & & \\
\hline \multirow{7}{*}{\multicolumn{2}{|c|}{ Perceived convenience $(\mathrm{PC})$}} & PC1 & .619 & \multirow{7}{*}{.885} & \multirow{7}{*}{.910} \\
\hline & & $\mathrm{PC} 2$ & .771 & & \\
\hline & & PC3 & .798 & & \\
\hline & & PC4 & .808 & & \\
\hline & & PC5 & .769 & & \\
\hline & & PC6 & .785 & & \\
\hline & & PC7 & .832 & & \\
\hline \multirow{7}{*}{\multicolumn{2}{|c|}{ Reader loyalty $(R L)$}} & RL1 & .570 & \multirow{7}{*}{.777} & \multirow{7}{*}{.801} \\
\hline & & RL2 & .708 & & \\
\hline & & RL3 & .728 & & \\
\hline & & RL4 & .751 & & \\
\hline & & RL5 & .564 & & \\
\hline & & RL6 & .653 & & \\
\hline & & RL7 & .600 & & \\
\hline
\end{tabular}




\section{B. Correlation analysis}

This study analyzed the empirical data, and the results are listed in "Table III". There is a significant correlation between the aesthetics, caring, information content of website service quality, and reader loyalty, with correlation coefficients of $0.511,0.402$, and 0.373 respectively; there is a significant correlation between the aesthetics, caring information content and perceived convenience of website service quality, with correlation coefficients of $0.428,0.294$, and 0.284 , respectively; perceived convenience is significantly related to reader loyalty, and the correlation coefficient is 0.422 . Therefore, the results of this correlation analysis initially support the hypothesis proposed in this study.

TABLE III. VARIABLE MEANS, STANDARD DEVIATIONS AND CORRELATION COEFFICIENTS BETWEEN VARIABLES

\begin{tabular}{|c|c|c|c|c|c|c|c|c|}
\hline & Gender & Age & $\begin{array}{c}\text { Education } \\
\text { level }\end{array}$ & Aesthetics & Caring & $\begin{array}{c}\text { Information } \\
\text { content }\end{array}$ & $\begin{array}{c}\text { Perceived } \\
\text { convenience }\end{array}$ & $\begin{array}{l}\text { Reader } \\
\text { loyalty }\end{array}$ \\
\hline Gender & 1 & & & & & & & \\
\hline Age & $.226^{* * * *}$ & 1 & & & & & & \\
\hline Education level & $.142 * *$ & $.279 * * *$ & 1 & & & & & \\
\hline Aesthetics & $.333 * * *$ & $.337 * * *$ & $.183 * * *$ & 1 & & & & \\
\hline Caring & $.224 * * *$ & $.244 * * *$ & .028 & $.330 * * *$ & 1 & & & \\
\hline $\begin{array}{c}\text { Information } \\
\text { content }\end{array}$ & $.236 * * *$ & $.297 * * *$ & $.185 * * *$ & $.307 * * *$ & $367 * * *$ & 1 & & \\
\hline $\begin{array}{c}\text { Perceived } \\
\text { convenience }\end{array}$ & $.200 * * *$ & $.306 * * *$ & $.147 * * *$ & $.428 * * *$ & $.294 * * *$ & $.284 * * *$ & 1 & \\
\hline Reader loyalty & $.305 * * *$ & $.405 * * *$ & $.117 * *$ & $.511 * * *$ & $.402 * * *$ & $.373 * * *$ & $.422 * * *$ & 1 \\
\hline Mean value & 1.41 & 2.18 & 2.52 & 4.115 & 4.076 & 4.110 & 4.107 & 4.30 \\
\hline Standard deviation & .556 & .593 & 1.086 & .971 & .979 & .942 & .995 & .903 \\
\hline
\end{tabular}

\section{Regression analysis}

In this study, the aesthetics, caring, and information content of the website service quality were used as independent variables, perceived convenience was used as an intermediate variable and gender, age, and education level were used as control variables. The readers' loyalty of the dependent variables was regressed.

1) Direct effects: A simple observation of the statistics provided in the above table shows that the effects of aesthetic, caring, and content are all positive, with standardized coefficients of $0.321,0.179$, and 0.135 respectively. Therefore, $\mathrm{H} 1 \mathrm{a}, \mathrm{H} 1 \mathrm{~b}$, and $\mathrm{H} 1 \mathrm{c}$ hold ("Table IV").

2) Analysis of intermediation: In the study, the median variable was tested according to the stepwise test method given in the article published by Baron. The first step is to conduct a regression analysis on the aesthetics, caring, and information content of independent variable website service quality to the dependent variable reader loyalty, and test the significance. The second step is to perform a regression analysis of the aesthetics, caring, and information content of the website service quality on the convenience of mediating variables. The aesthetics, caring, and standardization coefficients are 0.303, 0.121, and 0.089 respectively. The values are significant, assuming that $\mathrm{H} 2 \mathrm{a}, \mathrm{H} 2 \mathrm{~b}$, and $\mathrm{H} 2 \mathrm{c}$ hold. The third step is to carry out a regression analysis of the perceived convenience of the intermediary variable on the loyalty of the dependent variable readers. The standardization coefficient is 0.200 , assuming H3 holds. In the fourth step, under the condition of returning the independent variable and the mediating variable at the same time, the relationship between website service quality and reader loyalty is significantly reduced and the regression coefficients of aesthetics, caring and information content are reduced to $0.273,0.160$ and 0.199 respectively, indicating that there is still a significant positive impact. From the above results, it is clear that in the process of website service quality affecting readers' loyalty, perceived convenience plays a part of the mediating role, that is, H4 holds.

TABLE IV. INTERMEDIATE EFFECT LEVEL REGRESSION ANALYSIS RESULTS

\begin{tabular}{|c|l|l|l|l|}
\hline & CL & PC & CL & CL \\
\hline Control variable & & & & \\
\hline Gender & $.086^{*}$ & .041 & $.186 * * *$ & $.084 * *$ \\
\hline Age & $.085^{*} * *$ & $.133^{* *}$ & $.279 * * *$ & $.184 * * *$ \\
\hline Education level & -.041 & .031 & -.032 & -.046 \\
\hline Dependent variable & & & & \\
\hline $\boldsymbol{I B}$ & $.321 * * *$ & $.303 * * *$ & & $.273 * * *$ \\
\hline $\boldsymbol{I C}$ & $.179 * * *$ & $.121 * * *$ & & $.160 * * *$ \\
\hline $\boldsymbol{I I}$ & $.135^{*} *$ & $.098^{*}$ & & $.119 * *$ \\
\hline $\boldsymbol{P C}$ & & & $.323 * * *$ & $.159 * * *$ \\
\hline $\boldsymbol{R}^{\mathbf{2}}$ & .391 & .241 & .295 & .410 \\
\hline Adjusted $\boldsymbol{R}^{\mathbf{2}}$ & .379 & .226 & .285 & .396 \\
\hline $\boldsymbol{F}$ & 32.075 & 15.893 & 31.563 & 29.673 \\
\hline
\end{tabular}




\section{CONCLUSIONS AND IMPLICATIONS}

\section{A. Research conclusions}

Based on the TAM model, this study uses perceived convenience as an intermediate variable to study the mechanism between the service quality of online literature websites and reader loyalty. The validity, reliability, and correlation were tested. This study proved that all the hypothesis listed were true, and made the following conclusions:

First, reader loyalty is significantly positively affected by the service quality of online literature websites. Among them, aesthetics has the most impact on the loyalty of readers. The reason is that readers' first impressions of websites are mostly obtained through visual effects. The overall style and pattern of the website can directly impress readers and forming a good impression is conducive to readers forming reader loyalty. At the same time, the caring services provided by online literature websites for readers are one of the key factors that make readers loyal customers. The reason may be that the website's personalized services for readers can enhance the interactive experience, thereby virtually increasing their loyalty in attitudes and behaviors. In addition, high-quality information content can enhance the communication between the website and readers, and also has a direct influence on whether readers choose the website.

Second, the perceived convenience of consumers is significantly affected by the service quality of online literature websites. The three factors of website design service quality have similar effects on perceived convenience. This is similar to the reason that the three factors have different effects on reader loyalty, and the author will not elaborate here.

Third, perceived convenience has a significant positive impact on reader loyalty. The reason may be that when readers think that the website is easy to use and can improve reading efficiency, they will be more inclined to continue to pay attention to the website in the future, which is attitude loyalty. When readers feel the convenience of online literature websites, they will be more prone to buy novels and vote for works, which is behavioral loyalty.

Fourth, in the impact of website service quality on reader loyalty, perceived convenience plays a part of the mediating role. In other words, the service quality of online novel websites can indirectly affect reader loyalty by acting on perceived convenience. Therefore, the website can change the perceived convenience of readers by optimizing its own service quality, ensure the continuous development and operation of the website, and obtain a more ideal level of economic benefits.

\section{B. Marketing implications}

In order to promote readers to use online literature websites to read and increase readers' loyalty, it is believed that the following aspects should be improved and optimized.

1) Beautifying website design and building a good reputation: The beauty of web literature website design is the primary prerequisite for the rapid development of the website. Beauty is not only a key factor in determining a reader's first impression of the website, but also affects readers' attitudes and behavioral decisions in subsequent reading. Therefore, in the initial stage of the website, it is necessary to create a unique and impressive website interface as much as possible, explore your own unique design style, and improve the reading experience of readers. Here the author will take Hongxiu Tianxiang as an example. The target group of this website is female readers. Therefore, the website uses pink tones as a whole, which not only meets the female's aesthetic standards, but also echoes the website name and builds its own unique style. Most second-tier websites use yellow, green and blue colors, which can't give readers a deep visual impact.

2) Strengthening user stickiness and building independent communities: The caring quality of website service quality is also one of the measurement criteria for readers when choosing an online literature website. The online literature website can draw a psychological portrait of each user according to the reading preferences, reading habits and other relevant data of each reader, and push customized novels or services to users. From the perspective of the reader's actual reading needs, it is necessary to be reader-centered and ultimately achieve "content communication". Such measures can not only reduce the time cost for users to filter invalid information and search for target content, but also become a way to maintain social emotions, giving users a feeling of being cared about and valued.

The website can also establish a community similar to post bar to provide targeted support for communication and exchange between different subjects. In addition, the website can not only set up an online communication forum, but also hold offline reading sharing sessions, reading salons and lectures, and invite authors and readers to interact effectively in offline activities to further deepen the social relationship between the website and users.

3) Focusing on information content and strengthening copyright operations: The reader chooses the online literature website, which is basically to read the online literature and meet his own needs. Therefore, the website should not only focus on beautifying the website design and developing social relations, but also 
need to emphasize on serving readers as the core concept of the construction.

In addition to having a wide variety of clearly categorized browsing pages, the key to online literature website competition is whether it can conduct differentiated copyright operations. The website can be developed in a balanced manner on multiple types of content copyrights, and it can also focus on a certain type of copyright, thus forming its own unique brand and operating philosophy, enabling users to get selfimprovement while reading literature on the website as well as constantly strengthening their connection with the website, and paying for brand value. For example, China Literature currently focuses on the operation of copyright in online literature, such as "Fights break sphere" and so on. Furthermore, it has established its brand image as a highland of online fantasy literature among users.

4) Creating faddish IP and promoting industrial convergence: Since 2017, the number of adaptations of Internet literature into $\mathrm{TV}$ series has continued to increase, and many of them, such as "Time Raiders", have been well received, arousing heated social discussions and leading the viewing rate. Many film and television companies have begun work on the development and extension of the value of online literary works, and the IP industry with high-quality online text as its core is gradually maturing. In addition, the strong information promotion ability of the website itself is also of great positive significance for the development of online literature. This ability can provide core value elements for film, television, games, cultural and creative products derived from online literature, thereby creating a pan-entertainment industry integration and promoting the integrated development of the industry. Currently, the China Literature adopts this method to provide support for the deep exploration of the intrinsic value of online literature, to continuously create quality IP, and to continuously expand related industries such as animation, audio and peripherals.

\section{References}

[1] iResearch. Chinese Internet Literature Copyright Protection Research Report (Simplified Edition) in 2019 [EB / OL]. http://report.iresearch.cn/report_pdf.aspx?id=3378,2019-6-5. (in Chinese)

[2] Davis F D. Perceived Usefulness, Perceived Ease of Use, and User Acceptance of Information Technology [J]. MIS Quart $1989 ; 13(3)$.

[3] Wang Kai. Empirical Research on the Relationship between Shopping Website Design and Customer Loyalty [D]. East China Normal University, 2017. (in Chinese)

[4] DiegoBufquin, et al., International Journal of Hospitality Management, https://doi.org/10.1016/j.ijhm.2019.102378
[5] PZB. A Conceptual Mode of Service Quality and Its Implications for Future Research [J]. Journal Of Marketing, 1985

[6] Jiang Pinyu. Investigation and research on the service quality of ICBC's "finance e-purchase" e-commerce platform [D]. Anhui University, 2017. (in Chinese)

[7] Gronroos C. Marketing in Service Companies. Malmo Liber, 1983

[8] HEADLEY.D.E, MILLER.S.J. Measuring service quality and its relationship to future consumer behavior [J]. Journal of Health Care Marketing, 1993,13(4):32-41.

[9] JIANG.J.J, KLEIN.G, CRAMPTON.S.M. A note on SERVQUAL reliability and validity in information system service quality measurement [J]. Decision Sciences, 2007, 31(3):725-744.

[10] Zeithaml, V.A., Parasuraman, A., \& Malhotra, A. (2002) Service quality delivery through web sites: A critical review of extant knowledge. Journal of the Academy of Marketing Science, 30(4), 362-375.

[11] LOCACONO E, RICHARD TW,DALEG. WebQual: a web site quality instrument [Z]. Working Paper, 2000.

[12] E. Cristoal, C. Flavian, and M. Guinaliu (2007), "Perceived eservice quality: Measurement validity and effects on consumer satisfaction and web site loyalty", Managing Service Quality, Vol. 17 No. 3, pp. 317-340.

[13] Yang H W. Bon Appetite for Apps: Young American Consumers'Acceptance of Mobile Applications [J]. Journal of Computer Information Systems, 2013, 53(3): 85-96.

[14] O'CassA, FenechT. Web Retailing Adoption: Exploring the Nature of Internet Users Web Relating Behavior [J]. Journal of Retailing and Consumer Services,2003,(10).

[15] Hans van der He,den. Factors influencing the usage of websites: the case ofa generic portal in the Netherlands [J]. Information Management, 2003, 40(6): 541-549.

[16] M. Sundström and S. Hjelm-Lidholm, Re-positioning customer loyalty in a fast moving consumer goods market, Australasian Marketing Journal, https://doi.org/10.1016/j.ausmj.2019.09.004

[17] Magatef, S. G., \& Tomalieh, E. F. (2015). Impact of customer loyalty programs on customer retention. International Journal of Business and Social Science, 6(8), 78-93.

[18] Fishbeinm, Ajzeni. Belief, attitude, intention, and behavior: An introduction to theory and research reading [M]. MA:AddisonWesley, 1975

[19] Zeithmal, Berry L L, Parasuraman. The behavioral consequence of service quality. Journal of Marketing, 1996, 60(4): 31-46

[20] Dick, A. and Basu, K., 1994. Customer loyalty: towards an integrated framework. Journal of the Academy of Marketing Science 22 (2), 99-113.

[21] LiuC, Arnett KP. Exploring the factors associated with Website Success in the context of electronic commerce $[J]$. Information and Management, 2000, 38(1): 23-33.

[22] Gong Xiaoqing, Wang Xiaofeng. Research on the page design of regional specialty goods online stores [J]. Modern Decoration (Theory), 2016 (05): 108. (in Chinese)

[23] Tang Yijun. Webpage Strategy in Internet Marketing [D] Southwestern University of Finance and Economics, 2009. (in Chinese)

[24] Wei Chao, Chen Fei, Xu Danqing, Zhang Min, Liu Yiqun, Ma Shaoping. Research on Web Quality Evaluation System [J]. Journal of Chinese Information Processing, 2011, 25 (05): 3-8 (in Chinese)

[25] Ha Hong-Youl, Helen Perks. Effects of Consumer Perceptions of Brand Experience on the Web: Brand familiarity, Satisfaction and Brand Trust [J]. Journal of Consumer Behavior. 2005, 4(6) 438- 452 
[26] Shi Da. Research on the Relationship between Internet Customer Experience and Customer Website Loyalty - Based on Structural Equation Model [J]. Research on Financial and Economic Issues, 2009 (01): 30-36. (in Chinese)

[27] Gommans, M., Krishan, S., and Scheffold, K.B. FromBrandLoyalty to ELoyalty $[\mathrm{J}]$. Journal of Electronic Commerce Research, 2001, (3:1): 43-58.

[28] Martins, C., T. Oliveira, and A. Popovi čc. Understanding the Internet Banking Adoption: A Unified Theory of Acceptance and Use of Technology and Perceived Risk Application [J]. International Journal of Information Management, 2014, 34,(1) $: 1-13$.

[29] Chin-Lung Hsu, Hsi-Peng Lu. Why do people play on-line games? An extended TAM with social influences andflow experience Information and Management, 2004, (41): 853-868

[30] Zhang Fangfang, Analysis of Consumers' Willingness to Participate in Online Group Purchase [J]. Science and Technology Management, 2012, 14 (03): 33-37. (in Chinese)

[31] FENECH T, O'CASS A.Internet users' adoption of web retailing: user and product dimensions [J]. Journal of product\& brand management, 1992(6): 361-381

[32] Mc Dougall, Go rdon H G, Levesque, Terrence. Customer satisfaction with Services: Putting Perceived Value into the Equation [J]. Journal of Service Marketing, 2000(3)

[33] Zhou Jie, He Luping. The Impact of Service Quality on Customer Loyalty - Taking Customer Delight as the Mediating Variable [J]. Enterprise Economy, 2017, 36 (03): 9197. (in Chinese)

[34] Shi H P. An Empirical Study on Predicting User Acceptance of E-Shopping on the Web $[\mathrm{J}]$. Information and Management, 2004, 41(3): 351-368.

[35] Van Riel, A.C.R., Liljander, V, Jurriens, P. Exploring consumer evaluations of e-services: a portal site [J]. International Journal of Service Industry Management, 2001, 12(4): 359-377.

[36] Pavlou, P. A, and D. Gefen. Building Effective Online Marketplaces with Institution-based Trust [J]. Information systems research, 2004, 15, (1):37-59. 